\title{
AKTIVITAS ANTIOKSIDAN TEH KULIT LIDAH BUAYA (Aloe barbandensis miller) - ROSELA (Hibiscus sabdariffa L) DENGAN VARIASI LAMA PENGERINGAN
}

\author{
Antioxidan activitty of aloe vera tea (Aloe barbandensis miller) - rosela \\ (Hibiscus sabdariffa L) with drying time variation
}

\author{
Erik Lukman, Akhmad Mustofa, Yannie Asrie Widanti \\ Fakultas Teknologi dan Industri Pangan Universitas Slamet Riyadi Surakarta, \\ Jl. Sumpah Pemuda 17 Joglo Kadipiro Surakarta 57136 \\ Email: erikooops@gmail.com
}

\begin{abstract}
ABSTRAK
Aloe barbandensis miller yang kita kenal dengan nama lidah buaya adalah tanaman yang dapat tumbuh dengan cepat dan mudah dibudidayakan. Lidah buaya memiliki manfaat sebagai anti-inflamasi, anti jamur, anti bakteri untuk mengontrol tekanan darah. Tanaman lidah buaya sudah dikenal luas di Indonesia, khususnya di daerah pedesaan, tetapi belum dimanfaatkan secara maksimal dalam kehidupan sehari-hari. Penelitian dilakukan dengan menggunakan Rancangan Acak Lengkap (RAL) faktorial yang terdiri dari 2 faktor. Faktor pertama dengan rasio kulit lidah buaya dan rosela (2:1, 1:1, 1:2) sedangkan faktor yang kedua lama pengeringan $(60,70,80$ menit). Tujuan penelitian ini adalah untuk menghasilkan teh kering yang bersifat fungsional dan mengandung antioksidan tinggi serta disukai konsumen. Hasil penelitian menunjukkan kombinasi perlakuan rasio kulit lidah buaya dan rosela 1:3 dengan lama pengeringan 6o menit adalah yang paling optimal. Pemilihan ini didasarkan pada aktivitas antioksidan yang tinggi dan disukai konsumen. Pada perlakuan ini dihasilkan kadar air 7,91\%, kadar abu 5,12\%, total fenol 20,67\%, aktivitas antioksidan 55,98\%, $\mathrm{pH}$ 2,oo, serta uji organoleptik terhadap kesukaan keseluruhan yaitu 3,40 (suka).
\end{abstract}

Kata kunci: Antioksidan, teh, lidah buaya, rosella, pengeringan.

\begin{abstract}
Aloe barbandensis miller which are familiar with the name Aloe vera is a plant that can grow quickly and easily cultivated; aloe vera has benefits as anti-inflammatory, anti-fungal, anti-bacterial which control blood pressure. Aloe vera plant has been widely known in Indonesia, especially in rural areas, but not maximally utilized yet in everyday life. The research was conducted by using Factorial Random Design (RAL) which consist of 2 factors. The first factor was the ratio of aloe vera peel and roselle (2:1, 1:1, 1:2) while the second factor was drying time $(60,70,80 \mathrm{~min})$. The purpose of this study was to produce dry tea that is beneficial and contains high antioxidants and mostly chosed by consumers. The results showed that combination of treatment ratio between aloe vera skin and roselle was 1:3 with 6o minutes of drying time is the most optimal, in addition to high antioxidant activity and preferred by consumers. In this treatment the water content of $7.91 \%$, ash content of 5,12\%, total phenol $20.67 \%$, antioxidant activity $55.98 \%, \mathrm{pH} 2.00$, and organoleptic test to the overall preferences of 3.40 (likes).
\end{abstract}

keywords: Antioxidants, tea, aloe vera, roselle, drying

Jurnal Teknologi dan Industri Pangan 3 (2): 121-128 


\section{PENDAHULUAN}

Lidah buaya (Aloe barbandensis Miller) merupakan tanaman yang fungsional karena semua bagian dari tanaman ini dapat dimanfaatkan, misalnya untuk perawatan rambut dan mengobati penyakit. Manfaat lainnya dari lidah buaya sebagai anti-inflamasi, anti jamur, anti bakteri, untuk mengontrol tekanan darah, untuk regenerasi sel dan dapat juga sebagai nutrisi pendukung bagi penderita HIV (Widodo dan Budhiarti, 2006). Menurut Herlina (1997), Aloe vera banyak memiliki elemen yang dibutuhkan oleh tubuh manusia seperti vitamin, choline, inositol, asam folat, mineral, dan enzim. Bagian yang banyak dimanfaatkan adalah daging dari daunnya saja sementara kulitnya yang memiliki senyawa alonin dan Aloe emodin sering kali terbuang. Senyawa yang ada pada kulit lidah buaya tersebut memiliki kandungan anti bakteri yang dapat menjadi bahan pengawet alami.

Kulit daun lidah buaya dalam bentuk segar memiliki tingkat stabilitas yang rendah. Kulit daun segar mudah mengalami oksidasi akibat kontak dengan udara dan cahaya (Meadows, 1980). Untuk mencegah kerusakan akibat kontak langsung dengan udara maupun cahaya maka diperlukan perlakuan khusus dengan cara di -blanching yang akan meningkatkan stabilitas kulit lidah buaya. Karena kulit lidah buaya dengan kadar air yang kecil akan lebih awet daripada kadar air yang berlebihan. Manfaat kulit lidah buaya dapat ditemukan dalam minuman teh herbal yang dikeringkan dengan perlakuan steam blanching dan jenis pengering cabinet.

Selain lidah buaya, tanaman yang memiliki banyak manfaat adalah rosella. Rosela sebagai obat tradisional secara empiris berkhasiat sebagai antiseptik, diuretik, anti kejang, obat cacingan (antelmintik) dan sebagai anti bakteri. Bahan aktif yang terdapat dalam rosela adalah grossy peptin, anthocyanin, gluside hibiscin, dan flavonoid yang bermanfaat mencegah kanker, mengendalikan tekanan darah, melancarkan peredaran darah, dan sebagainya. Kandungan seratnya cukup tinggi yang berperan dalam melancarkan sistem pembuangan dan menurunkan kadar kolestrol dalam darah
(Erianto, 2009).

Melihat manfaat yang sangat baik dari kulit lidah buaya dan rosela maka keduanya dapat disatukan menjadi suatu produk yaitu menjadi teh kulit lidah buaya-rosella. Penelitian ini mempelajari tentang aktivitas antioksidan teh kulit lidah buaya-rosela dengan perlakuan rasio kulit lidah buaya-rosela dan lama pengeringan untuk menghasilkan kualitas teh lidah buaya-rosela yang disukai konsumen dan kaya akan antioksidan.

\section{METODE PENELITIAN \\ Alat dan Bahan Penelitian}

Alat yang digunakan yaitu timbangan, cabinet dryer, pisau, sendok, baskom, loyang, sedangkan untuk peralatan analisis: Timbangan, kompor listrik, $\mathrm{pH}$ meter, tabung reaksi, rak, pipet volume, spectrometer, crush, memmert. Bahan kimia yang digunakan antara lain etanol, methanol, aquades, reagen Folin Cio Calteau, dan $\mathrm{Na}_{2} \mathrm{CO}_{3}$.

Bahan yang digunakan dalam penelitian yaitu kulit lidah buaya yang diperoleh dari daerah sekitar Solo, dan rosela yang diperoleh dari Pasar Gede Surakarta.

\section{Rancangan Percobaan}

Dalam penelitian ini rancangan percobaan yang digunakan adalah rancangan acak lengkap faktorial, dengan faktor pertama yaitu rasio kulit lidah buaya dan rosela (3:1, 1:1, 1:3), dan faktor kedua yaitu lama pengeringan (6o, 70, 80 menit). Dari rancangan percobaan tersebut diperoleh 9 kombinasi perlakuan dan masingmasing perlakuan diulang sebanyak tiga kali. Data yang diperoleh dianalisis dengan uji sidik ragam pada jenjang nyata o,05. Jika ada beda nyata dilanjutkan uji Tukey untuk mengetahui beda nyata antar perlakuan pada tingkat signifikasi $5 \%$.

\section{CARA PENELITIAN \\ Pembuatan Teh Kulit Lidah Buaya- Rosela}

Langkah awal dari pembuatan teh kulit lidah buaya-rosela ini adalah pengeringan dengan cara sortasi kulit lidah buaya dan bunga rosela, daun lidah buaya dikupas dan diambil 
kulitnya, kulit lidah buaya dan bunga rosela dicuci dan dibersihkan dari kotoran, lakukan penirisan kulit lidah buaya dan bunga rosela (untuk kulit lidah buaya setelah ditiriskan, di iris
- iris $\pm 1 \mathrm{~cm})$. Kulit lidah buaya dan rosela kering diambil sesuai perlakuan untuk membuat teh, 2:1, 1:1, 1:2 kebutuhan setiap perlakuan dapat dilihat pada tabel 1.

Tabel 1. Kebutuhan Tiap Perlakuan

\begin{tabular}{ccc}
\hline $\begin{array}{c}\text { Kombinasi } \\
\text { perlakuan }\end{array}$ & $\begin{array}{c}\text { Kulit lidah } \\
\text { buaya }\end{array}$ & Rosella \\
\hline $1: 1$ & $1 \mathrm{~g}$ & $1 \mathrm{~g}$ \\
$2: 1$ & $1,3 \mathrm{~g}$ & $0,7 \mathrm{~g}$ \\
$1: 2$ & $0,7 \mathrm{~g}$ & $1,3 \mathrm{~g}$ \\
\hline
\end{tabular}

Kulit lidah buaya dan rosela kemudian dikeringkan sesuai perlakuan, 6o, 70, dan 80 menit dengan suhu $60{ }^{\circ} \mathrm{C}$ dengan kabinet dryer. Setelah kulit lidah buaya dan rosela kering maka langkah selanjutnya adalah pembuatan seduhan teh kulit lidah buaya-rosela (Setiawan,
2004), yakni dengan cara mengambil kulit lidah buaya dan rosela kering sesuai perlakuan untuk membuat teh dengan total kebutuhan $25 \mathrm{~g}$. Perlakuan seduhan teh kulit lidah buaya dan rosela dapat dilihat pada tabel 2.

Tabel 2. Seduhan Teh Kulit Lidah Buaya-Rosella

\begin{tabular}{cccc}
\hline $\begin{array}{c}\text { Kombinasi } \\
\text { perlakuan }\end{array}$ & Kulit lidah buaya & Rosela & Air \\
\hline $1: 1$ & $12,50 \mathrm{~g}$ & $12,50 \mathrm{~g}$ & $1,250 \mathrm{ml}$ \\
$2: 1$ & $16,67 \mathrm{~g}$ & $8,340 \mathrm{~g}$ & $1,250 \mathrm{ml}$ \\
$1: 2$ & $8,340 \mathrm{~g}$ & $16,67 \mathrm{~g}$ & $1,250 \mathrm{ml}$ \\
\hline
\end{tabular}

Setelah itu masukkan kulit lidah buaya dan rosela kering dalam gelas sesuai perlakuan, didihkan air 1,250 ml murni sampai mendidih, berdasarkan kebutuhan analisis selanjutnya tuangkan ke dalam gelas yang telah berisi kulit lidah buaya dan rosella, tutup dan biarkan selama 5 menit kemudian disaring, dan teh kulit lidah buaya-rosela siap dikonsumsi.

\section{CARA PENGUMPULAN DATA}

Pada penelitian ini dilakukan analisis kimia dan uji organoleptik. Analisis kimia meliputi: analisis aktivitas antioksidan (Yen dan Chen, 1995), kadar fenol dengan metode Candler dan Dodds yang dimodifikasi (Shetty et al., 1995), kadar abu dengan metode termogravimetri (Sudarmadji et al., 1997), kadar air dengan metode termogravimetri (Sudarmadji et al., 1997), analisis $\mathrm{pH}$ dengan $\mathrm{pH}$ meter (Apriyantono, 1989) dan uji organoleptik pada penelitian ini meliputi warna, rasa, aroma, tekstur dan kesukaan keseluruhan pada panelis terhadap produk teh yang dibuat. Pengujian organoleptik ini menggunakan 15 orang sebagai panelis. 
Tabel 3. Rangkuman Hasil Analisis Kimia Teh Kulit Lidah Buaya- Rosela dengan lama pengeringan.

\begin{tabular}{|c|c|c|c|c|c|c|}
\hline \multirow[b]{2}{*}{$\begin{array}{c}\text { Lama } \\
\text { Pengeringan }\end{array}$} & \multirow{2}{*}{$\begin{array}{c}\text { Rasio } \\
\text { Kulit } \\
\text { Lidah } \\
\text { Buaya : } \\
\text { Rosela }\end{array}$} & \multicolumn{5}{|c|}{ Analisis Kimiawi } \\
\hline & & $\begin{array}{c}\text { Kadar } \\
\text { Air } \\
(\%)\end{array}$ & $\begin{array}{c}\text { Kadar } \\
\text { Abu } \\
(\%)\end{array}$ & $\begin{array}{c}\text { Aktivitas } \\
\text { Antioksidan } \\
(\%)\end{array}$ & $\begin{array}{c}\text { Total } \\
\text { Fenol } \\
(\%)\end{array}$ & $\begin{array}{c}\text { Derajat } \\
\text { Keasaman }\end{array}$ \\
\hline \multirow{3}{*}{60 menit } & $1: 1$ & $7.88 \mathrm{e}$ & $4.23 a$ & $49.81 a$ & $17 \cdot 50 \mathrm{a}$ & $2.53 \mathrm{C}$ \\
\hline & $2: 1$ & 7.73de & $3.97 a$ & $48.14 a$ & $15.47 a$ & $3.25 \mathrm{e}$ \\
\hline & $1: 2$ & $7 \cdot 91 \mathrm{e}$ & $4.54 a$ & $55 \cdot 98 \mathrm{a}$ & $20.67 a$ & $2.00 a$ \\
\hline \multirow{3}{*}{70 menit } & $1: 1$ & $7 \cdot 43 \mathrm{C}$ & $4.42 \mathrm{a}$ & $48.91 a$ & $17.25 \mathrm{a}$ & $2.64 \mathrm{C}$ \\
\hline & $2: 1$ & $7 \cdot 36 \mathrm{bc}$ & $4.25^{a}$ & 46.46a & $15 \cdot 30 a$ & $3 \cdot 52 \mathrm{f}$ \\
\hline & $1: 2$ & $7 \cdot 52 \mathrm{~cd}$ & $4.84 a$ & $54.08 \mathrm{a}$ & $20.22 \mathrm{a}$ & $3 \cdot 52 \mathrm{f}$ \\
\hline \multirow{3}{*}{80 menit } & $1: 1$ & $7.03 a$ & $4.61 a$ & $47 \cdot 51 a$ & 17.00a & $3.00 d$ \\
\hline & $2: 1$ & $6.99 a$ & $4 \cdot 47 a$ & $45 \cdot 92 a$ & $15.07 a$ & $4.65 \mathrm{~g}$ \\
\hline & $1: 2$ & $7.15 \mathrm{ab}$ & $5.12 \mathrm{a}$ & $52.81 a$ & 20.09a & $2.34 \mathrm{~b}$ \\
\hline
\end{tabular}

\section{HASIL DAN PEMBAHASAN}

\section{Kadar Air Teh Kulit Lidah Buaya - Rosela}

Hasil penelitian analisis kimia teh kulit lidah buaya dan rosela dapat dilihat pada tabel 3 . Hasil analisis sidik ragam menunjukkan bahwa perlakuan rasio kulit lidah buaya-rosela dan lama pengeringan berbeda nyata terhadap kadar air teh sedangkan pada perlakuan kombinasi keduanya berbeda tidak nyata terhadap kadar air teh. Purata kadar air teh kulit lidah buaya dan rosela berkisar antara 6,99\% sampai 7,91 \%. Purata pengukuran kadar air teh menunjukan bahwa purata tertinggi yaitu $7,91 \%$ dengan rasio kulit lidah buaya- rosela (1:2) dengan lama pengeringan 60 menit sedangkan purata kadar air terendah yaitu 6,99\% dengan rasio kulit lidah buaya-rosela (2:1) dengan lama pengeringan 80 menit. Semakin tinggi penambahan rasio rosela maka kadar air teh tersebut semakin bertambah. Hal ini disebabkan kadar air rosela kering lebih tinggi daripada kadar air kulit lidah buaya kering. Kadar air rosela kering sebesar 9,42\% (Winarti, 2015) sedangkan kulit lidah buaya memiliki kadar air sebesar 4,9-5,3\% (Hartulistyoso et al., 2011).

Berdasarkan syarat mutu yang dikeluarkan SNI 3836:2013, teh kering mengandung kadar air maksimal 8\%, sehingga teh kulit lidah buayarosela sudah memenuhi standar tersebut karena kadar air teh kulit lidah buaya-rosela berada di bawah batas maksimum yang telah ditentukan SNI 3836:2013.

\section{Kadar Abu Teh Kulit Lidah Buaya - Rosella}

Hasil analisis sidik ragam menunjukkan bahwa perlakuan rasio kulit lidah buaya-rosella, lama pengeringan dan kombinasi keduanya berbeda tidak nyata terhadap kadar abu teh. Purata kadar abu teh kulit lidah buaya dan rosela berkisar antara 3,97\% sampai 5,12\%. Purata pengukuran kadar abu teh menunjukan bahwa purata tertinggi yaitu 5,12\% dengan rasio kulit lidah buaya-rosela (1:2) dengan lama pengeringan 6o menit sedangkan purata kadar abu terendahyaitu 3,97\% dengan rasio kulit lidah buaya-rosela (2:1) dengan lama pengeringan 8o menit. Kadar abu pada teh cenderung menurun seiring dengan penambahan lama waktu pengeringan. Hal ini disebabkan semakin lama proses pengeringan akan meningkatkan kadar abu pada teh kering yang dihasilkan. Kadar abu dari lidah buaya kering per $100 \mathrm{~g}$ bahan 1,39\% sedangkan kadar abu bunga rosela kering 6,9\% (Winarti et al. 2015).

Berdasarkan syarat mutu yang dikeluarkan SNI 3836:2013, teh kering mengandung kadar abu maksimal 8\%, sehingga teh kulit lidah buaya dan rosela sudah memenuhi standar SNI 3836:2013 yaitu di bawah batas maksimum 8 yang telah ditentukan.

\section{Aktivitas Antioksidan Teh Kulit Lidah Buaya - Rosella}

Hasil analisis sidik ragam menunjukkan 
bahwa perlakuan rasio kulit lidah buaya-rosela berbeda nyata terhadap aktivitas antioksidan sedangkan lama pengeringan dan kombinasi keduanya berbeda tidak nyata terhadap aktivitas antioksidan teh. Purata aktivitas antioksidan teh kulit lidah buaya dan rosela berkisar antara 45,92\% sampai 55,98\%. Purata pengukuran aktivitas antioksidan teh menunjukan bahwa purata tertinggi yaitu $55,98 \%$ dengan rasio kulit lidah buaya-rosela (1:2) dengan lama pengeringan 60 menit sedangkan purata aktivitas antioksidan terendah yaitu 45,92\% dengan rasio kulit lidah buaya-rosela (2:1) dengan lama pengeringan 80 menit. semakin tinggi konsentrasi rosela yang ditambahkan maka aktivitas antioksidan semakin meningkat. Hal ini disebabkan rosela mengandung antioksidan. Semakin tinggi penambahan rosela maka kandungan antioksidan pada teh kulit lidah buaya dan rosela semakin meningkat. Aktivitas antioksidan rosela yaitu 99,05 \% (Winarti et al., 2015) sedangkan aktivitas antioksidan kulit lidah buaya sekitar 12-13,8\% (Agus et al., 2015). Semakin lama pengeringan maka aktivitas antioksidan semakin menurun. Pada suhu pengeringan yang tinggi senyawa antioksidan yang berfungsi pada teh dari kulit lidah buaya akan mengalami kerusakan, sedangkan sebaliknya, apabila suhu pengeringan yang rendah akan mendapatkan aktivitas antioksidan yang baik (Agus et al., 2015).

\section{Total Fenol Teh Kulit Lidah Buaya - Rosella}

Hasil analisis sidik ragam menunjukkan bahwa perlakuan rasio kulit lidah buayarosela berbeda nyata terhadap total fenol teh sedangkan lama pengeringan dan kombinasi keduanya berbeda tidak nyata terhadap total fenol teh. purata total fenol teh kulit lidah buaya dan rosela berkisar antara 15,07\% sampai 20,67\%. Purata pengukuran total fenol teh menunjukan bahwa purata terendah yaitu
15,07\% dengan rasio kulit lidah buaya-rosela (2:1) dengan lama pengeringan 80 menit sedangkan purata total fenol tertinggi yaitu 20,67\% dengan rasio kulit lidah buaya-rosela 1:2 dengan lama pengeringan 60 menit.

Semakin tinggi konsentrasi rosela yang ditambahkan maka total fenol semakin meningkat. Hal ini disebabkan rosela mengandung kandungan fenolik. Semakin tinggi penambahan rosela maka total fenol pada teh kulit lidah buaya dan rosela semakin meningkat. Kandungan fenol pada kulit lidah buaya sebesar $22,70 \%$ pada suhu $60^{\circ} \mathrm{C}$ dalam 5 menit sedangkan pada rosela sebesar 22,01\% pada suhu $50^{\circ} \mathrm{C}$ dalam 30 jam (Winarti et al., 2015). Menurut Faridasari dan Mulyantini (2009), dalam penelitian metode pengeringan rosela menggunakan alat pengering yang paling efektif untuk mengeringkan rosella.

\section{pH Teh Kulit Lidah Buaya - Rosella}

Hasil analisis sidik ragam menunjukkan bahwa perlakuan rasio kulit lidah buaya-rosella, lama pengeringan dan kombinasi keduanya berbeda nyata terhadap $\mathrm{pH}$ teh. $\mathrm{pH}$ tertinggi pada teh kulit lidah buaya-rosela yaitu 4,65 diperoleh dari perlakuan rasio kulit lidah buayarosela (2:1) dan lama pengeringan 80 menit. $\mathrm{pH}$ terendah yaitu 2,oo diperoleh dari perlakuan rasio kulit lidah buaya-rosela 1:2 dan lama pengeringan 60 menit.

Semakin tinggi konsentrasi rosela yang ditambahkan maka $\mathrm{pH}$ semakin menurun (asam). Hal ini disebabkan kandungan asam yang dihasilkan oleh bunga rosela sangat tinggi, jadi $\mathrm{pH}$ yang dihasilkan sangat rendah sehingga menjadi asam (Apriantono, 1989). Semakin rendah nilai pH dikarenakan semakin tinggi dan lama proses pengeringan yang akan mempercepat penguapan dan menyebabkan kandungan dalam ekstrak berkurang sehingga mempengaruhi kadar pH. (Hamidah et al., 2014). 
Tabel 4. Rangkuman Hasil Uji Organoleptik Teh Kulit Lidah Buaya-Rosela dengan Lama Pengeringan

\begin{tabular}{|c|c|c|c|c|c|c|}
\hline \multirow{2}{*}{$\begin{array}{c}\text { Lama } \\
\text { Pengeringan }\end{array}$} & \multirow{2}{*}{$\begin{array}{c}\text { Rasio Kulit } \\
\text { Lidah Buaya : } \\
\text { Rosella }\end{array}$} & \multicolumn{5}{|c|}{ Uji Organoleptik } \\
\hline & & Warna & $\begin{array}{l}\text { Rasa } \\
\text { Pahit }\end{array}$ & $\begin{array}{l}\text { Flavor Kulit } \\
\text { lidah buaya }\end{array}$ & $\begin{array}{l}\text { Flavor } \\
\text { Rosella }\end{array}$ & $\begin{array}{c}\text { Kesukaan } \\
\text { keseluruhan }\end{array}$ \\
\hline \multirow{3}{*}{60 menit } & $1: 1$ & $2.47 \mathrm{a}$ & $3.20 a$ & $2.67 a$ & $2.67 a$ & $2.60 a$ \\
\hline & $2: 1$ & $2.27 \mathrm{a}$ & $3.40 a$ & $3.20 \mathrm{a}$ & $2.20 \mathrm{a}$ & $2.33 a$ \\
\hline & $1: 2$ & $3.20 a$ & $2.60 a$ & $2.47 \mathrm{a}$ & $2.93 a$ & $3.00 a$ \\
\hline \multirow{3}{*}{70 menit } & $1: 1$ & $2.60 a$ & $3.07 a$ & $2.60 a$ & $2.60 a$ & $2.47 \mathrm{a}$ \\
\hline & $2: 1$ & $2.53 a$ & $3.33 a$ & $3.20 \mathrm{a}$ & $2.27 \mathrm{a}$ & $2.47 \mathrm{a}$ \\
\hline & $1: 2$ & $3.27 \mathrm{a}$ & $2.67 a$ & $2.53 a$ & $3.13 a$ & $3.13 a$ \\
\hline \multirow{3}{*}{80 menit } & $1: 1$ & $2.80 \mathrm{a}$ & $2.80 a$ & $2.47 \mathrm{a}$ & $2.53 a$ & $2.60 a$ \\
\hline & $2: 1$ & $2.60 a$ & $3.20 \mathrm{a}$ & $3.07 a$ & $2.60 a$ & $2.47 \mathrm{a}$ \\
\hline & $1: 2$ & $3.40 a$ & $2.53 a$ & $2.13 a$ & $2.60 a$ & $3.27 a$ \\
\hline
\end{tabular}

Warna: Angka tertinggi menunjukan warna semakin kemerahan

Rasa pahit: Angka tertinggi menunjukan rasa semakin pahit

Flavor Lidah Buaya: Angka tertinggi menunjukan flavor lidah buaya semakin terasa

Flavor Rosella: Angka tertinggi menunjukan flavor rosela semakin terasa

Kesukaan Keseluruhan: Angka tertinggi menunjukan teh semakin disukai

\section{Uji Organoleptik Teh Kulit Lidah Buaya - Rosella \\ Warna Teh Kulit Lidah Buaya - Rosella}

Hasil penelitian analisis organoleptik dapat dilihat pada tabel 4. Hasil analisis sidik ragam menunjukkan bahwa perlakuan rasio kulit lidah buaya-rosela berbeda nyata sedangkan lama pengeringan dan kombinasi keduanya berbeda tidak nyata terhadap warna teh. warna teh yang sangat kuning kemerah - merahan $(3,40)$ diperoleh dari perlakuan rasio kulit lidah buayarosela (1:2) dengan lama pengeringan 80 menit sedangkan warna teh tidak kuning kemerah merahan $(2,27)$ pada perlakuan rasio kulit lidah buaya: rosela (2:1) dengan lama pengeringan 60 menit.

Semakin tinggi rasio rosela maka warna teh cenderung semakin merah, karena bunga rosela mempunyai pigmen antosianin yang membuat teh tersebut merah. Lama pengeringan mempengaruhi warna teh tersebut karena semakin lama pengeringan maka semakin merah (Agus et al., 2015). Rendemen pewarna merah cair dari ekstrak bunga rosela semakin menurun dengan semakin meningkatnya suhu ekstraksi. Hal ini disebabkan karena ekstraksi antosianin juga dipengaruhi oleh suhu dimana asam menguap jika dipanaskan sehingga komponen volatil yang terekstrak juga menguap. Dengan semakin meningkatnya suhu maka terlarutnya pigmen antosianin semakin baik (Farida et al., 2013).

\section{Rasa Pahit Teh Kulit Lidah Buaya -Rosella}

Hasil analisis sidik ragam menunjukkan bahwa perlakuan rasio kulit lidah buaya-rosela berbeda nyata sedangkan lama pengeringan dan kombinasi keduanya berbeda tidak nyata terhadap rasa pahit teh. rasa pahit yang terasa $(3,40)$ diperoleh perlakuan rasio kulit lidah buaya-rosela (2:1) dan lama pengeringan 6o menit. Semakin tinggi rasio kulit lidah buaya maka semakin terasa rasa pahit teh tersebut. Rasa pahit yang tidak terasa (2.53) pada perlakuan rasio kulit lidah buaya-rosela (1:2) dan lama pengeringan 80 menit.

\section{Flavor Khas Lidah Buaya Teh Kulit Lidah Buaya - Rosella}

Hasil analisis sidik ragam menunjukkan bahwa perlakuan rasio kulit lidah buaya-rosela berbeda nyata sedangkan lama pengeringan dan kombinasi keduanya berbeda tidak nyata terhadap flavor kulit lidah buaya teh. flavor kulit lidah buaya yang terasa $(3,20)$ diperoleh perlakuan rasio kulit lidah buaya-rosela (2:1) dan lama pengeringan 60 menit. Semakin tinggi rasio kulit lidah buaya maka semakin terasa rasa 
flavor tersebut. Flavor kulit lidah buaya yang tidak terasa (2.13) pada perlakuan rasio kulit lidah buaya-rosela (1:2) dan lama pengeringan 80 menit. Hal ini disebabkan semakin lama pengeringan maka flavor semakin tidak terasa.

\section{Flavor Khas Lidah Buaya Teh Kulit Lidah Buaya - Rosella}

Hasil analisis sidik ragam menunjukkan bahwa perlakuan rasio kulit lidah buaya-rosela berbeda nyata sedangkan lama pengeringan dan kombinasi keduanya berbeda tidak nyata terhadap flavor rosela pada teh. falvor rosela yang terasa $(3,13)$ diperoleh perlakuan rasio kulit lidah buaya-rosela 1:2 dan lama pengeringan 80 menit. Semakin tinggi rasio rosela maka semakin terasa rasa flavor tersebut. Flavor rosela yang tidak terasa $(2,20)$ pada perlakuan rasio kulit lidah buaya-rosela 2:1 dan lama pengeringan 60 menit. Hal ini disebabkan semakin lama pengeringan maka flavor semakin terasa flavor rosella.

\section{Kesukaan Keseluruhan Rasio Teh Kulit Lidah Buaya-Rosella}

Hasil analisis sidik ragam menunjukkan bahwa perlakuan rasio kulit lidah buayarosela berbeda nyata sedangkan lama pengeringan dan kombinasi keduanya berbeda tidak nyata terhadap kesukaan teh. kesukaan panelis yang paling tinggi $(3,27)$ diperoleh perlakuan rasio kulit lidah buayarosela 1:2 dan lama pengeringan 80 menit sedangkan kesukaan keseluruhan paling rendah $(2,33)$ yaitu perlakuan rasio kulit lidah buaya-rosela 2:1 dan lama pengeringan 60 menit. Panelis lebih menyukai rasa rosela yang asam daripada rasa pahit pada kulit lidah buaya, sehingga semakin banyak rasio rosela maka panelis semakin menyukainya.

\section{KESIMPULAN}

Konsentrasi masing-masing perlakuan berpengaruh terhadap kadar antioksidan teh kering. Semakin tinggi konsentrasi rosela maka kadar antioksidan semakin meningkat. Aktivitas antioksidan tertinggi yaitu pada perlakuan rasio kulit lidah buaya-rosela 1:2 dan lama pengeringan 60 menit yaitu sebesar $55,98 \%$. Teh yang paling disukai $(3,00)$ ada- lah teh dengan perlakuan rasio daun kelor dan rosela sebesar 1:2 dan lama pengeringan selama 60 menit.

\section{DAFTAR PUSTAKA}

Agus W.S., Luh Putu W., Gusti Ayu L.T. 2015. Pengaruh Suhu Pengeringan Dan Ukuran Potongan Terhadap Karakteristik Teh Kulit Lidah Buaya. Skripsi Universitas Adiyana .

Apriyantono, A., 1989. Petunjuk Laboratorium Analisis Pangan. Bogor: PAU Pangan dan Gizi Institut Pertanian Bogor

Farida A., Ferawati., Risma A. 2013. Ekstraksi Zat Warna dari Kelopak Bunga Rosela (Studi Pengaruh Konsentrasi Asam Asetat dan Asam Sitrat). Jurnal Teknik Kimia. (19): 26-34

Hamidah T., Kumalaningsih., Dewi. 2014. Pembuatan Ekstrak Oleoresin Daun Sirih Hijau (Piper bettle L.) sebagai Pengawet Alami (Kajian Suhu dan Lama Ekstraksi). Jurnal Lulusan TIP FTP Universitas Brawijaya. Vol 2 (8): 1-8.

Hartulistiyoso E., Rokhani H., Eka P. 2011. Pengeringan Lidah Buaya menggunakan Oven Gelombang Mikro. Jurnal Teknik Pertanian (19): 141-146.

Herlina, Lien, 1997. Lidah Buaya Tanaman Hias Yang Kaya Manfaat. Jakarta: Majalah Selera.

Meadoswn P., 1980. Aloe Vera Heals: The Scientific Fact. Denver, Colorado: Royal Publication, Inc.

Setiawan, O. V. I., 2004. Variasi Blanching dan Jenis Pengeringan Pembuatan Teh Lidah Buaya.Skripsi.Surakarta: Universitas Slamet Riyadi

Shetty, K, Curtis, O.F., Levin, RE., Witkowsky, R. dan Ang, W. 1995. Prevention of Vitrification Associated with in Vitro Shooot Culture of Oregano (Origanum vulgare)by Pseudomanas spp. J.Plant Physiol (147): 447-451.

Sudarmadji S, Bambang H, Suhardi. 2010. Analisa Bahan Makanan dan Pertanian. Yogyakarta: Liberty.

Widodo, P. dan U.Budhiarti. 2006. Mengebunkan Lidah Buaya secara Intensif. Jakarta: PT. 
Argomedia Pustaka.

Winarti S., Sudaryati, Dina S.U. 2015. Karakteristik dan Aktivitas Antioksidan Rosela Kering. Jurnal Rekapangan (9): 17-24.
Yen, G. O. dan Chen, H. Y., 1995. Antioksidan Activity of Various Tea Extract in Relation to their Antimutagenicity. Journal Agricultural Food Chemistry (43): 27-32. 